\title{
Author Correction: Functional cooperativity between the trigger factor chaperone and the ClpXP proteolytic complex
}

Kamran Rizzolo (10, Angela Yeou Hsiung Yu, Adedeji Ologbenla, Sa Rang Kim, Haojie Zhu, Koichiro Ishimori (D), Guillaume Thibault (D), Elisa Leung, Yi Wen Zhang, Mona Teng, Marta Haniszewski, Noha Miah, Sadhna Phanse (1), Zoran Minic, Sukyeong Lee, Julio Diaz Caballero (1), Mohan Babu (D), Francis T. F. Tsai, Tomohide Saio \& Walid A. Houry (1)

Correction to: Nature Communications https://doi.org/10.1038/s41467-020-20553-x, published online 12 January 2021.

The original version of this Article contained an error in the spelling of the author Sa Rang Kim, which was incorrectly given as SaRang Kim.

This has now been corrected in both the PDF and HTML versions of the Article.

Published online: 06 May 2021

\footnotetext{
(c) (i) Open Access This article is licensed under a Creative Commons Attribution 4.0 International License, which permits use, sharing, adaptation, distribution and reproduction in any medium or format, as long as you give appropriate credit to the original author(s) and the source, provide a link to the Creative Commons license, and indicate if changes were made. The images or other third party material in this article are included in the article's Creative Commons license, unless indicated otherwise in a credit line to the material. If material is not included in the article's Creative Commons license and your intended use is not permitted by statutory regulation or exceeds the permitted use, you will need to obtain permission directly from the copyright holder. To view a copy of this license, visit http://creativecommons.org/licenses/by/4.0/.
}

(c) The Author(s) 2021 